\title{
The Effect of Solution Treatment Temperature and Quenching Media Variation in Heat Treatment Process Cu-Zn-Al Shape Memory Alloys on Shape Memory Effect and Microstructures
}

\author{
Wikan Jatimurti $^{1 *}$, Monica Gayatri $\mathrm{K}^{1}$, Mavindra Ramadhani ${ }^{1}$, Rochman Rochiem ${ }^{1}$ \\ ${ }^{1}$ Department of Materials and Metallurgical Engineering, Institut Teknologi Sepuluh Nopember, Jalan \\ Kampus ITS, Surabaya, 60111, Indonesia \\ *wikan@material.its.ac.id
}

\section{ABSTRACT}

Shape memory alloys (SMAs) are metal alloys with a reversible ability to recover their shape at a certain temperature after being deformed. This ability referred to as Shape Memory Effect (SME). The application of SMAs such as Ni-Ti and $\mathrm{Cu}-\mathrm{Zn}-\mathrm{Al}$ alloys usually used on automotive, biomedical, etc. The commonly used SMA is Ni-Ti because of its superior SME properties than $\mathrm{Cu}-\mathrm{Zn}$-Al, even though the price is quite higher. The SME of $\mathrm{Cu}-\mathrm{Zn}-\mathrm{Al}$ might be improved by increasing the presence of the martensite phase in its microstructure by heat treatment. The heat treatment process given to $\mathrm{Cu}-21 \mathrm{Zn}-5 \mathrm{Al}$ alloy is a homogenizing, annealing, solution treatment process and quenched with brine solution and dry ice. The heat-treated alloys then undergo several examination trough hardness tests, X-Ray Diffraction, metallography, SME test, and Differential Scanning Calorimetry to determine the SME and microstructure of $\mathrm{Cu}-21 \mathrm{Zn}-5 \mathrm{Al}$. From the test results, the specimen with temperature treatment solution of $850 \mathrm{oC}$ and quenched by brine solution had the highest SME value by $36.67 \%$. All of the microstructure contained $\alpha, \beta$, (martensite) and $\gamma$ phases.

Copyright (C) 2020. Journal of Mechanical Engineering Science and Technology

All rights reserved.

Keywords: Cu-Zn-Al alloy, heat treatment, shape memory alloy

\section{Introduction}

Shape Memory Alloys (SMAs) are smart material with ability to remember or to reverse the former shapes in response to heat, magnetic fields or electromagnetic waves after being deformed. This ability called by Shape Memory Effect (SME). These unique properties allowed SMAs to utilized in various fields such as actuators in automotive field and blood clotting filter devices in medical field. Both of these tools utilized SME ability to remember or reverse shape back to former shape in response to the shift of temperature by surrounding environment. The SME ability is closely related to the microstructure of the alloy in the presence of a martensite phase. The martensitic phase at room temperature is twinned martensite and easily deformed then, The martensitic phase of deformed SMAs is detwinned martensite. If detwinned martensite phase provided by a shift of temperature, a transformation would occur such as reserve transformation to austenite phase through a heating process then the austenite phase undergoes forward transformation to austenite phase through a cooling process and the SMAs restore its former shape. The transformation involves changes in the alloy's crystal structure [1].

In general, SMAs often used are Ni-Ti. Ni-Ti alloys have a superior SME (above 8\%) but a fairly expensive price. An alternative to substitute $\mathrm{Ni}-\mathrm{Ti}$ alloys as SMAs is $\mathrm{Cu}$-based 
alloys, especially $\mathrm{Cu}-\mathrm{Zn}-\mathrm{Al}$ alloys with a lower price and SME ability than Ni-Ti alloys. The SME ability in $\mathrm{Cu}-\mathrm{Zn}-\mathrm{Al}$ alloys is $4-5 \%$. The $\mathrm{SME}$ of $\mathrm{Cu}-\mathrm{Zn}-\mathrm{Al}$ might be improved by increasing the presence of the martensite phase in its microstructure by heat treatment. The heat treatment is based on the $\mathrm{Cu}-\mathrm{Zn}$ - $\mathrm{Al}$ ternary phase diagram and the intended heat treatment objectives such as homogenization, annealing, and solution treatment. For this reason, this study was conducted to determine the effect of variations temperature solution treatment and quenching media on SME and microstructure of shape memory alloys $\mathrm{Cu}-\mathrm{Zn}$ $\mathrm{Al}[2]$.

\section{Material and Methods}

The method includes research chronological, including research design, research procedure (in the form of algorithms, Pseudocode or other), instruments, and analysis techniques used in solving problems. Experimental procedures should be given in sufficient detail to allow these to be replicated by other researchers. The source of the various reagents and materials used in the study should be given, where possible.

\section{A. Material}

The specimen is X-Ray Fluorescence (XRF) tested by PANalytical MiniPal4 XRF. Table 1 shows the composition of Cu-21 Zn-5 Al shape memory alloys based on the ASM standards and as cast.

Table 1. Composition $\mathrm{Cu}-21 \mathrm{Zn}-5 \mathrm{Al}$ shape memory alloys

\begin{tabular}{lcrr}
\hline \multirow{2}{*}{ Annotation } & \multicolumn{3}{c}{ Composition } \\
\cline { 2 - 4 } ASM Handbook Volume 2 & $\mathrm{Cu}(\%)$ & $\mathrm{Zn}(\%)$ & $\mathrm{Al}(\%)$ \\
$\begin{array}{l}\text { Chapter: Shape Memory Alloy } \\
\text { As Cast }\end{array}$ & Balance & $10-35$ & $4-10$ \\
\hline
\end{tabular}

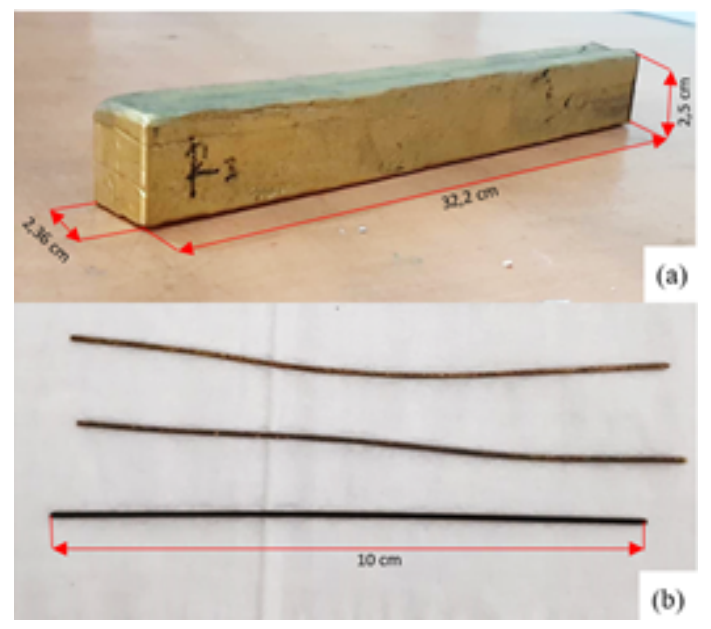

Fig. 1. $\mathrm{Cu}-21 \mathrm{Zn}-5 \mathrm{Al}$ alloys (a) as cast; (b) after the machining process

Figure 1(a) shows as cast of $\mathrm{Cu}-21 \mathrm{Zn}-5 \mathrm{Al}$ alloy with dimension length, width and height of $32.2,2.36$ and $2.5 \mathrm{~cm}$. The $\mathrm{Cu}-21 \mathrm{Zn}-5 \mathrm{Al}$ alloy is yellow colored-like brass in general. Then the machining process is carried out on the alloy using a CNC wire cutting tool. 
Figure 1(b) shows $\mathrm{Cu}-21 \mathrm{Zn}-5 \mathrm{Al}$ alloy after the machining process as the form of a wire with a diameter and length of $1 \mathrm{~mm}$ and $10 \mathrm{~cm}$. The wire is test specimens for the effect of memory shape test in accordance with ASTM F2082 standards.

\section{B. Material Preparation}

A homogenization treatment performed at $850^{\circ} \mathrm{C}$ for 2 hours followed with air cooling, was undertaken to improve the chemical and microstructural homogeneity in $\mathrm{Cu}-21 \mathrm{Zn}-5 \mathrm{Al}$ alloys. The alloys with dimension length, width and height of $1,2.36$, and $2.5 \mathrm{~cm}$. The machined $\mathrm{Cu}-21 \mathrm{Zn}-5 \mathrm{Al}$ alloys annealed at $550^{\circ} \mathrm{C}$ for 4 hours with air cooling and thereafter, solution treatment with temperature variation at 750,850 , dan $900^{\circ} \mathrm{C}$ followed by variations quenching media such as brine solution and dry ice. The samples for the research are 7, which consist of AC, 750-BC, 750-DC, 850-BC, 850-DC, 900-BC, and 900-DC. The number on sample stands for solution treatment's temperature variation, $\mathrm{BC}$ means brine solution cooling, DC mean dry ice-cooling, and AC means as-cast alloy.

\section{Vickers Hardness Test}

The Vickers hardness tests were undertaken to determine the hardness value of $\mathrm{Cu}$ $21 \mathrm{Zn}-5 \mathrm{Al}$ alloy for identifying the material's resistance to localized plastic deformation induced by indentation. The Vickers hardness tests were performed by Universal Hardness Tester HBRV 187.5 A with a diamond pyramid indenter with a square base and an angle of 136o between opposite faces. The samples and method for the Vickers hardness test were prepared following standard procedures of ASTM E92-17. The test involves delivering 30 $\mathrm{kgf}$ load for 10 seconds trough the indenter at 3 different points on each sample. The samples are as cast and after solution treatment process of $\mathrm{Cu}-21 \mathrm{Zn}-5 \mathrm{Al}$ alloy.

\section{X-Ray Diffraction (XRD)}

$\mathrm{X}$-Ray Diffraction (XRD) analysis was undertaken for the phase characterization of the $\mathrm{Cu}-21 \mathrm{Zn}-5 \mathrm{Al}$ alloys produced. The samples for the analysis were prepared following standard procedures dimension with length, width, and height of $2.5,1$, and $0.4 \mathrm{~cm}$. The analysis was performed by PAN Analytical XRD test equipment with diffraction $2 \theta$ angle spectral range of $10^{\circ}$ to $90^{\circ}$. The XRD analysis was determined by PAN Analytical High Score Plus-Marven software to compare the peaks formed with International Center for Diffraction Data (ICDD) standard data according to the phase characterization. The samples are as cast and after solution treatment process of $\mathrm{Cu}-21 \mathrm{Zn}-5 \mathrm{Al}$ alloy.

\section{E. Metallographic Examination}

The observation of the microstructure of the $\mathrm{Cu}-21 \mathrm{Zn}-5 \mathrm{Al}$ alloy was studied using OLYMPUS BX51M-RF optical microscope. The samples for the observation were prepared following standard procedures of ASTM E-407. The samples were etched by immerse method with $\mathrm{FeCl}_{3}+\mathrm{HCl}+\mathrm{H}_{2} \mathrm{O}$ solution for 10 seconds to reveal the microstructure. The metallographic observation was undertaken on as cast and after solution treatment of $\mathrm{Cu}$ $21 \mathrm{Zn}-5 \mathrm{Al}$ alloy. The samples are as cast and after solution treatment process of $\mathrm{Cu}-21 \mathrm{Zn}$ $5 \mathrm{Al}$ alloy.

\section{F. Different Scanning Calorimetry (DSC)}

The Shape Memory Effect (SME) test was undertaken to determine the percentage of recovery in deformed $\mathrm{Cu}-21 \mathrm{Zn}-5 \mathrm{Al}$ alloys. The samples for the analysis were prepared following standard procedures of ASTM F2082 with dimension of a wire with a diameter and length of $1 \mathrm{~mm}$ and $10 \mathrm{~cm}$. The sample is $\mathrm{Cu}-21 \mathrm{Zn}-5 \mathrm{Al}$ wire after the solution treatment 
process. The SME test involves cooling a test sample to its nominally fully martensitic phase, bending the sample at $20^{\circ}$, and heating the sample to its fully austenitic phase.

After heating, the angle of the sample is measured and calculated by equation (1), as in:

$$
S M E=\frac{\theta o-\theta t}{\theta o} \times 100 \%
$$

Where: $\theta_{0}$ : Initial angle

$\theta_{\mathrm{t}}$ : Final angle

\section{Results and Discussions}

The results of Vickers hardness test for all sample is given in Figure 2. The highest value of hardness Vickers (HV) is Sample 750-BC, and the smallest value of HV is Sample $\mathrm{AC}$. $\mathrm{Cu}-21 \mathrm{Zn}-5 \mathrm{Al}$ alloys have $\alpha, \beta$, and martensite phase as the main microstructures.

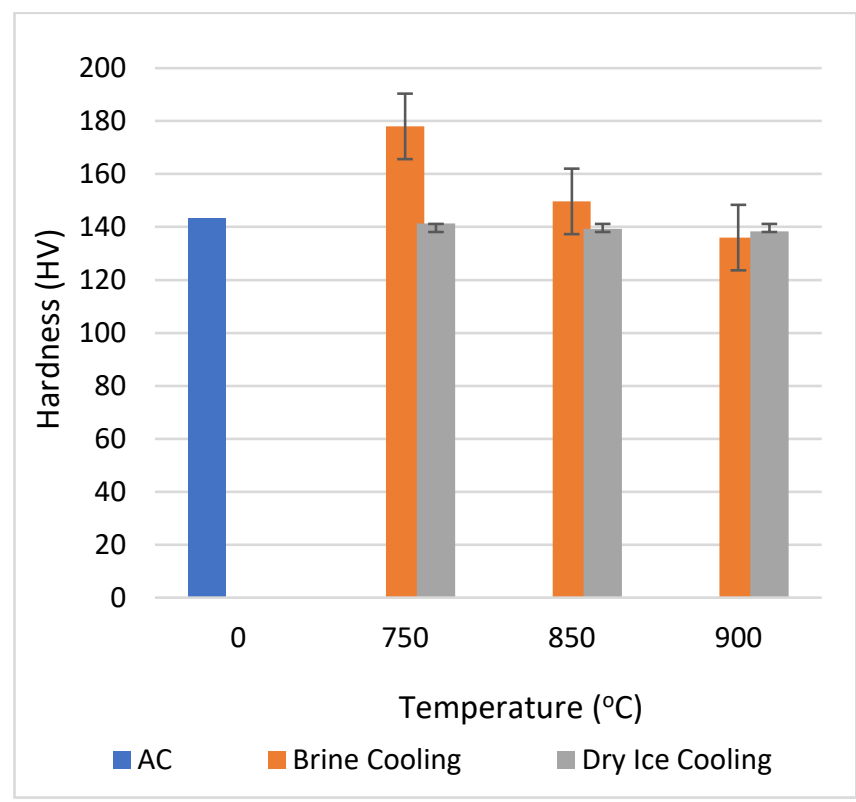

Fig. 2. Hardness of investigated $\mathrm{Cu}-21 \mathrm{Zn}-5 \mathrm{Al}$ alloy

The characteristic of $\alpha$ phase is more lenient than $\beta$ phase [3]. he hardness of $\mathrm{Cu}-\mathrm{Zn}-\mathrm{Al}$ shape memory alloys comes from $\beta$ phase, because its properties as hard and brittle. Aluminum can increase the existance of $\beta$ phase and hardness value [4]. As in martensite in steel, martensitic properties are hard and brittle. However, in shape memory alloys, the nature of martensite is soft and resilient [5]. The microstructure with more amount of $\alpha$ and martensite phase will make the HV value smaller. In addition to the types of phases, the grain shape can affected the value of $\mathrm{HV}$. The value of $\mathrm{HV}$ in microstructures with finer grains are higher than the one with coarser grains [6].

The XRD pattern of $\mathrm{Cu}-21 \mathrm{Zn}-5 \mathrm{Al}$ alloys quenched by dry ice and solution treatment is shown in Figure 3 and Figure 4. The diffraction pattern represents the crystal lattice of the $\alpha$-brass, $\beta$-brass, and $\gamma$-brass phases. According to the chemical composition of investigated alloy, it can be expected that alloy consists of 3 phases $(\alpha, \beta$, and $\gamma)$, which is confirmed by the XRD pattern. According to the $\mathrm{Cu}-\mathrm{Zn}-\mathrm{Al}$ ternary diagram, the presence of $\alpha$ and $\beta$ phases 
indicated the potential ability of SME and the martensitic phase formed. The pattern of Sample AC and $\mathrm{Cu}-21 \mathrm{Zn}-5 \mathrm{Al}$ alloys quenched by dry ice shown a more dominant presence of the $\alpha$-brass phase than the $\beta$ phase. On the contrary, the Sample of $\mathrm{Cu}-21 \mathrm{Zn}-5 \mathrm{Al}$ alloys quenched by dry ice shown a more dominant presence of the $\beta$-brass phase than the $\alpha$-brass phase.

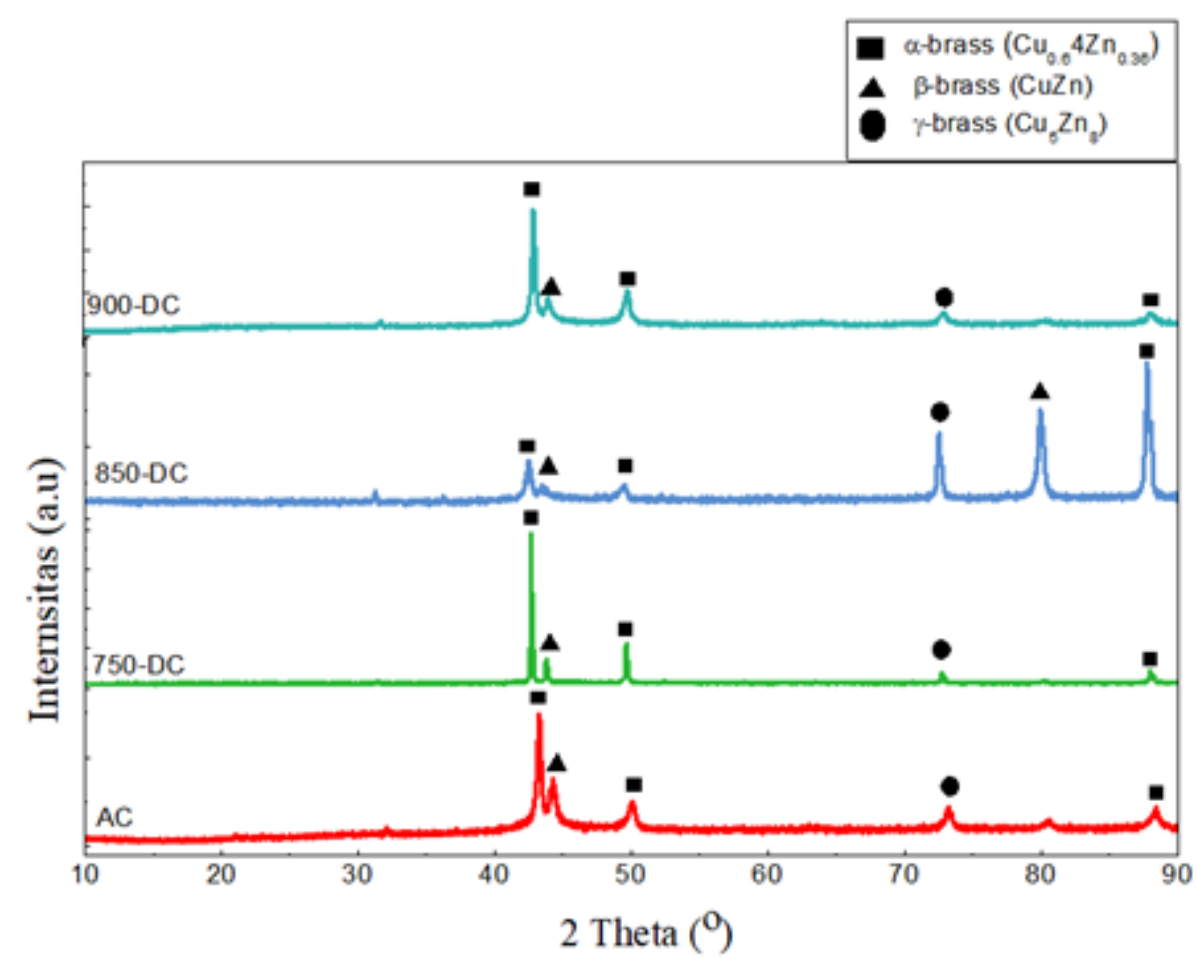

Fig. 3. XRD pattern of $\mathrm{Cu}-21 \mathrm{Zn}-5 \mathrm{Al}$ alloys quenched by dry ice.

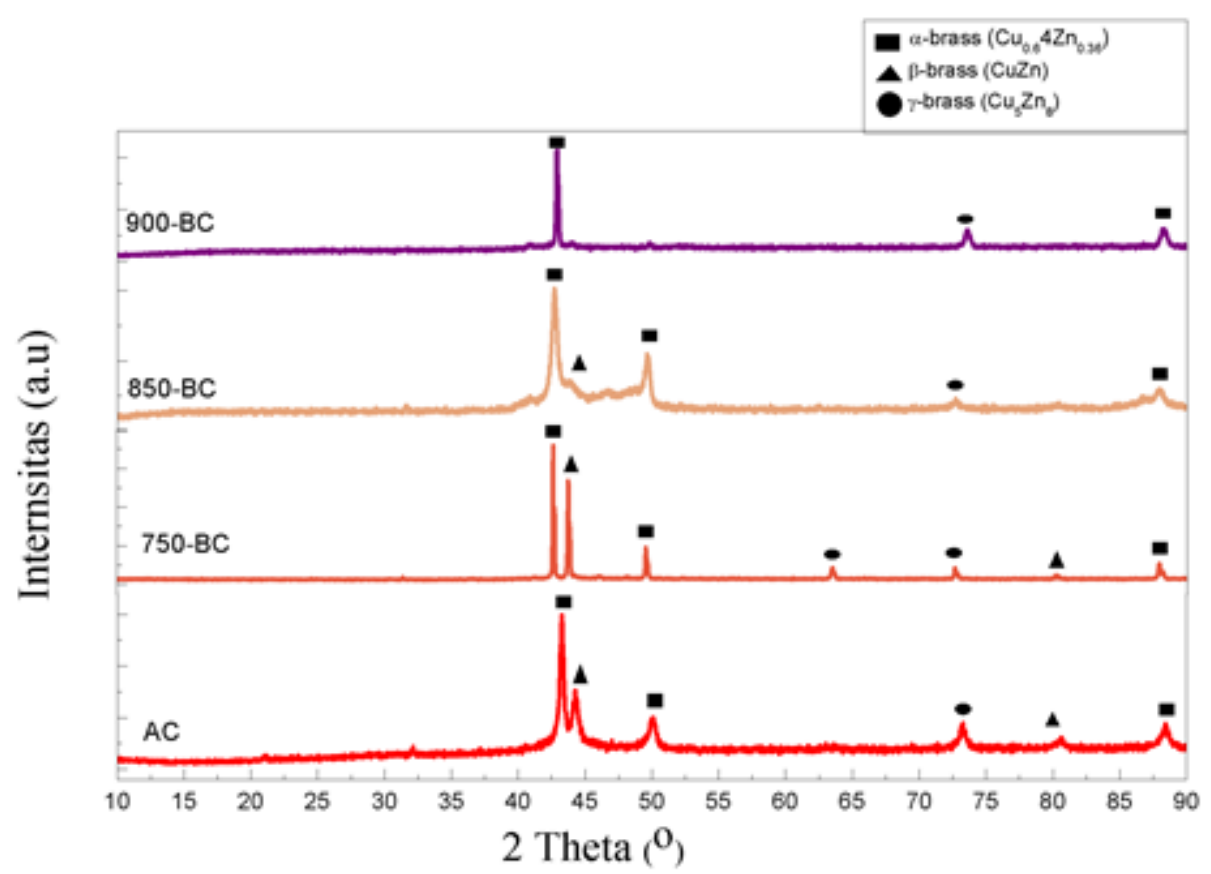

Fig. 4. XRD pattern of $\mathrm{Cu}-21 \mathrm{Zn}-5 \mathrm{Al}$ alloys quenched by brine solution. 
The microstructure observation of $\mathrm{Cu}-21 \mathrm{Zn}-5 \mathrm{Al}$ alloy analyzed by comparing the percentage of phases using FIJI app in Figure 5. The result shown a formation of 4 phases namely $\alpha, \beta, \beta^{\prime}$ (martensite) and $\gamma$.

The results of metallography analysis using optical microscopy for Sample AC is given in Figure 6 The optical microscopy reveals that the microstructure of Sample AC consist of $\alpha$ phase the irregularly light colored shaped grains, $\beta$ phase the dark colored grains due to corrosion from etching process, and $\gamma$ phase the black dot shaped grain [7]. The formed phases are similar with the XRD pattern from the same sample.

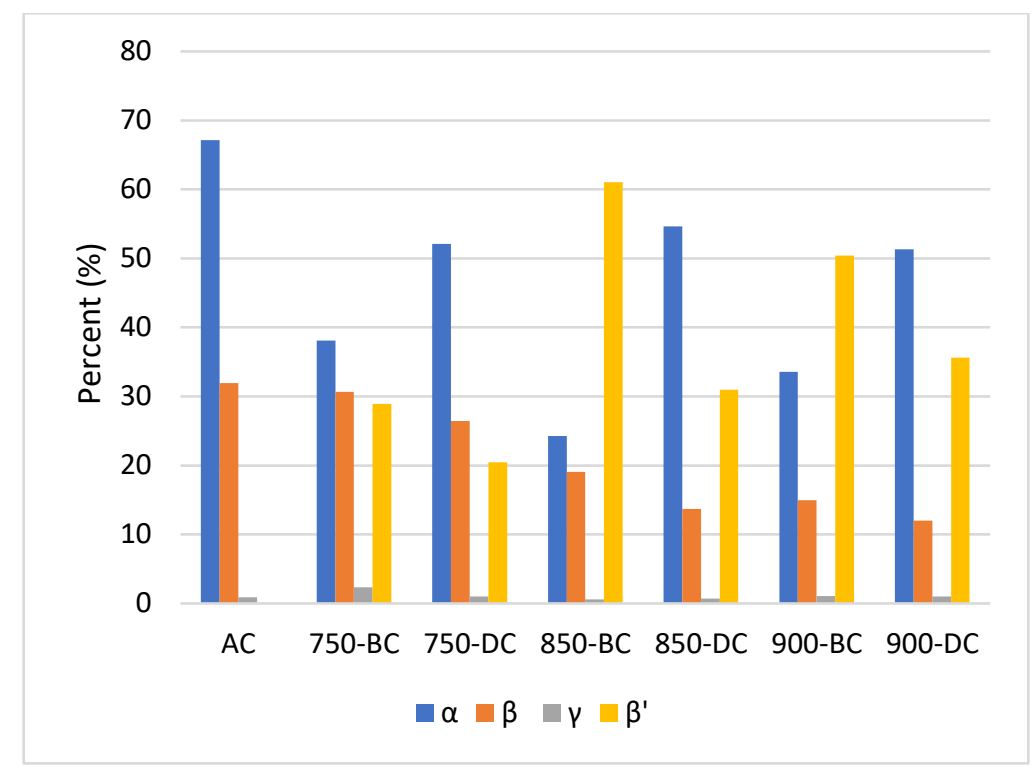

Fig. 5 The percentage of phases in $\mathrm{Cu}-21 \mathrm{Zn}-5 \mathrm{Al}$

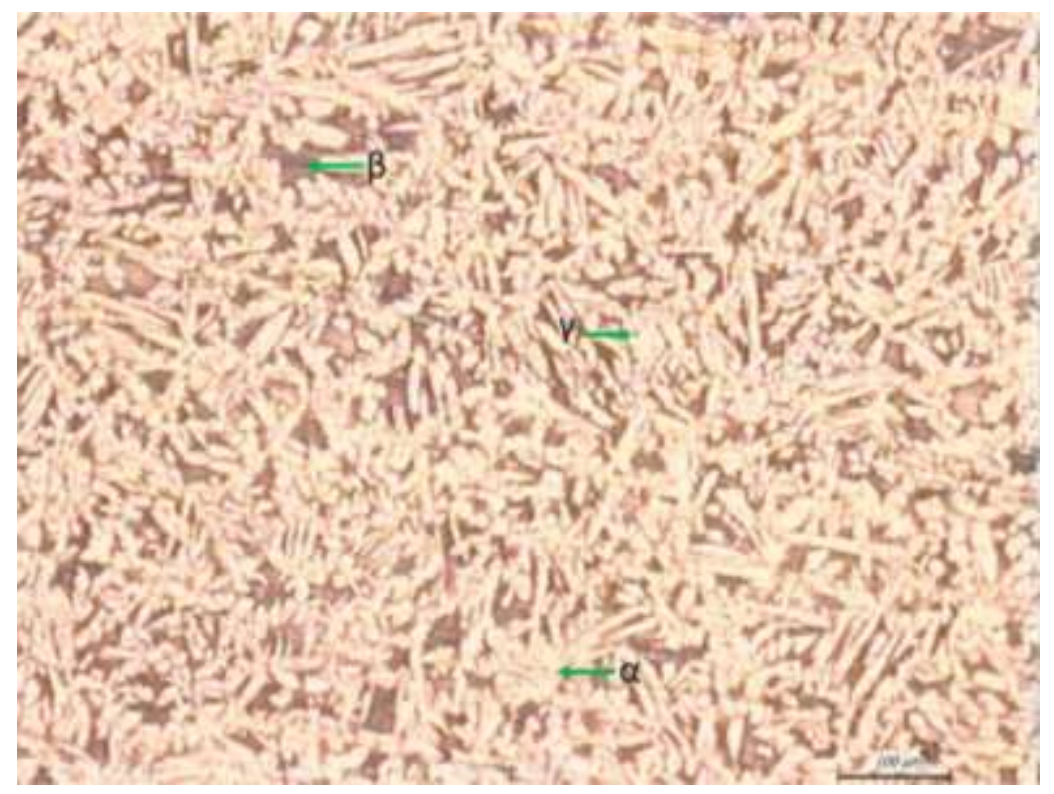

Fig. 6 The microstructure of sample AC with 100X magnitude 
The results of metallography analysis using optical microscopy for Sample 750-BC, 850-BC, and 900-BC is given in Figure 7. The optical microscopy reveals Sample 750-BC, 850-BC, and 900-BC have the same microstructure as Sample AC which is consist of the same 3 phases $(\alpha, \beta$, and $\gamma)$ but with additions martensite $\left(\beta^{\prime}\right)$ phases. The martensite phase formed by a dissolved $\alpha$ phase in $\beta$ phase as the consequence of quenching a single phase form at such a high rate that the atoms do not have time to diffuse out of the crystal structure in large enough quantities [8]. In $\mathrm{Cu}-21 \mathrm{Zn}-5 \mathrm{Al}$ alloy's case the appeared martensite phase caused by a solution treatment at high temperature until the full $\beta$ phase then quenched at high rate by brine solution [9].

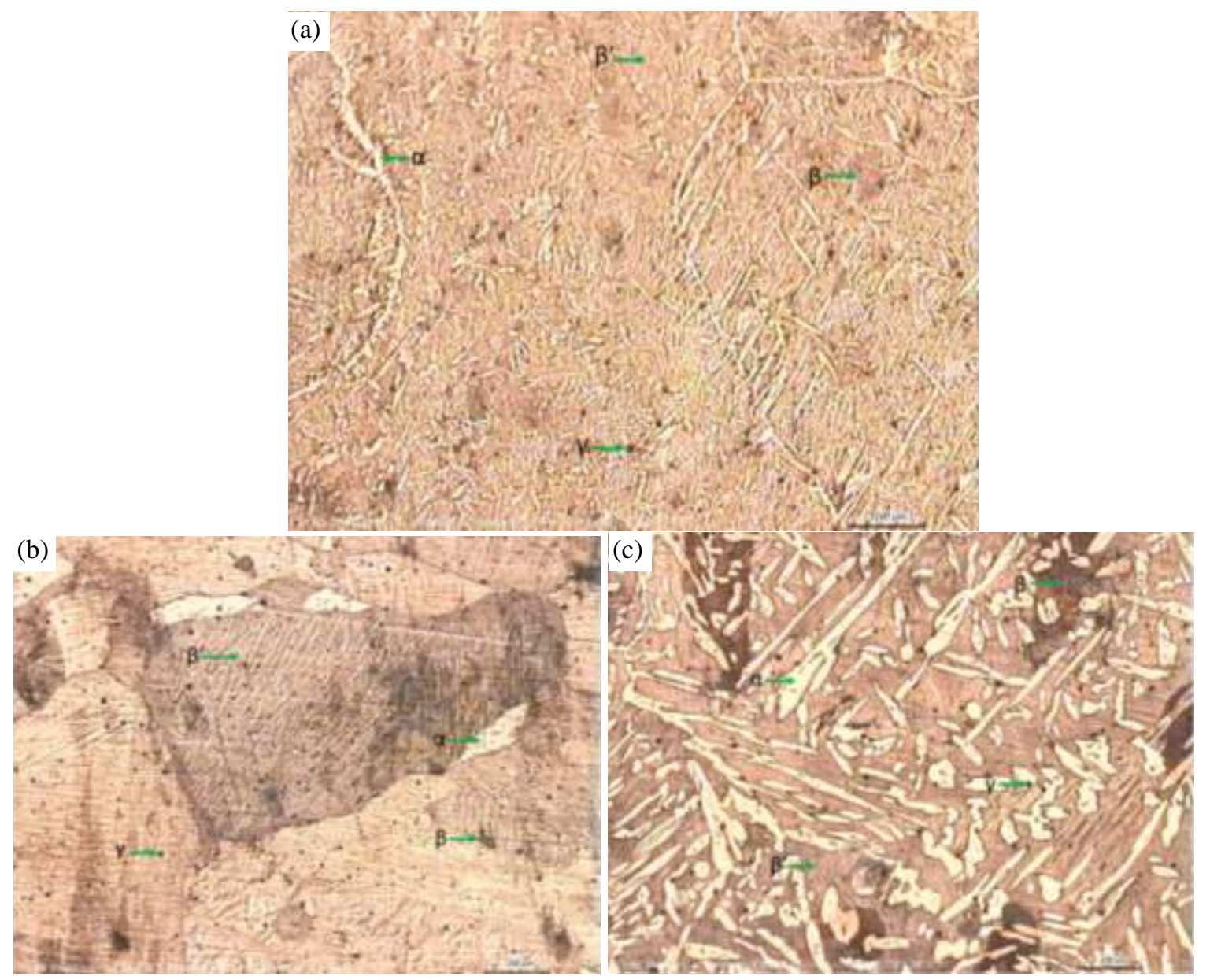

Fig. 7 The microstructure of Sample (a) 750-BC; (b) 850-BC; and (c) 900-BC with 100X magnitude

The results of metallography analysis using optical microscopy for Sample 750-DC, 850-DC, and 900-DC is given in Figure 8. The optical microscopy reveals Sample Cu-21Zn$5 \mathrm{Al}$ alloy quenched by dry ice have the same microstructure as Sample $\mathrm{Cu}-21 \mathrm{Zn}-5 \mathrm{Al}$ alloy quenched by brine solution which is consist of the same 4 phases $(\alpha, \beta, \gamma$, and martensite). It's also shown from Figure 4 and Figure 5, the effect of the higher variation temperature solution treatment is a larger or coarser the grains formed. The effect of different quenching media is the amount of martensite phase in each sample. The sample with brine solution as quenching media have larger amount than the other sample [10]. 


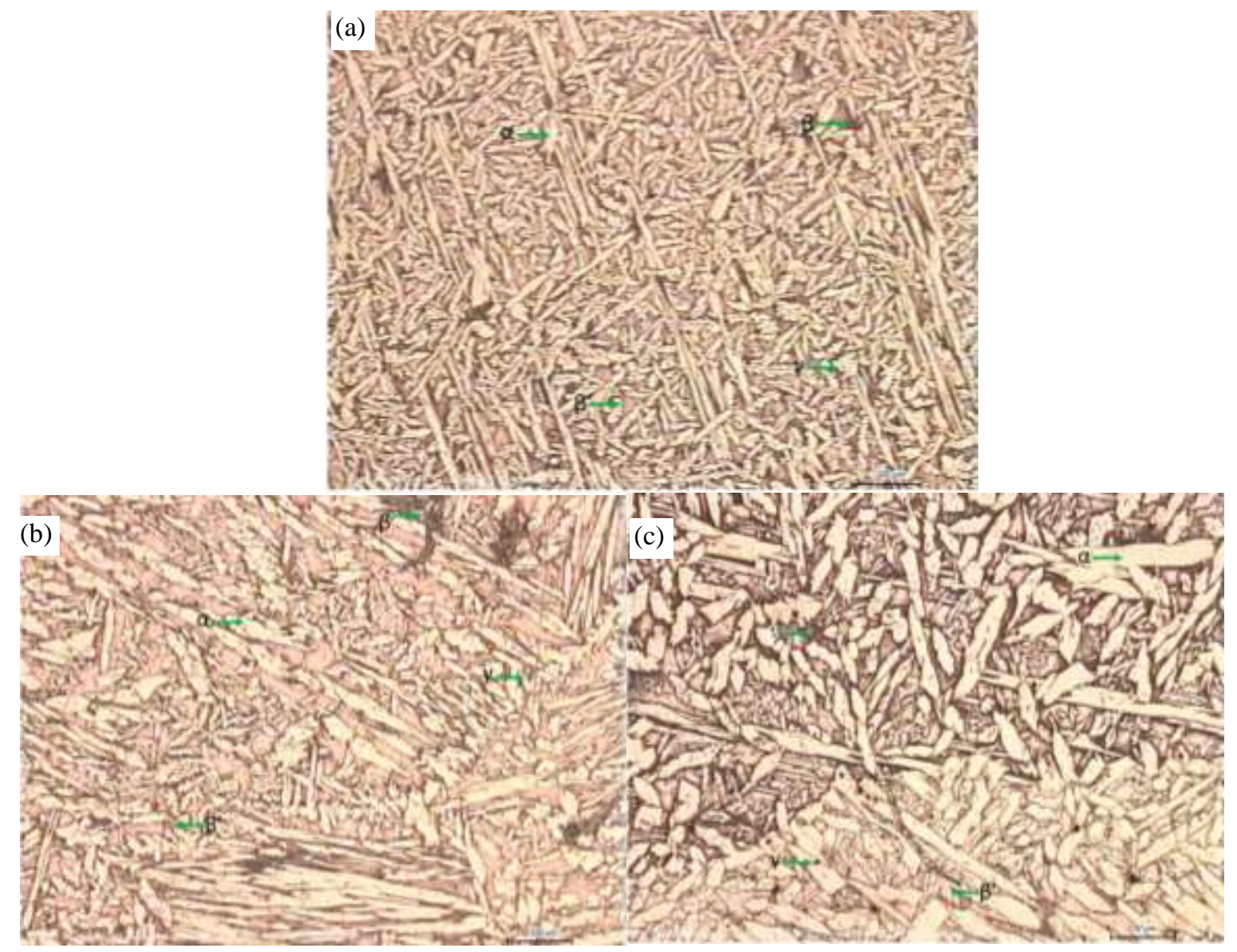

Fig. 8. The microstructure of Sample (a) 750-DC; (b) 850-DC; and (c) 900-DC with 100X magnitude

The pattern Differential Scanning Calorimetry (DSC) of Cu-21Zn-5Al shown in Figure 9. The pattern shown 2 peaks with the first peak on the left caused by an exothermic reaction and the second peak on the right caused by an endothermic reaction. The formation of these two peaks is in accordance with the principle of DSC based on ASTM E2253 to analyze the exothermic reaction [11].

Exothermic and endothermic reactions occur due to reactions that absorb energy and release energy at certain range temperature [12]. In $\mathrm{Cu}-21 \mathrm{Zn}-5 \mathrm{Al}$ alloy, the reaction takes the form of a phase change from martensite to austenite and vice versa with temperature range shown in Table 2. The temperature range of the DSC pattern in Figure 8 in accordance with ASTM F2005-00 for standard graph of SMAs having two temperature transformation peaks. The two temperature transformation peaks referred as the martensitic transformation temperature $\left(\mathrm{M}_{\mathrm{s}}\right.$ and $\left.\mathrm{M}_{\mathrm{f}}\right)$ and the austenitic transformation temperature $\left(\mathrm{A}_{\mathrm{s}}\right.$ and $\left.\mathrm{A}_{\mathrm{f}}\right)$.

Table 2. The temperature transformation of $\mathrm{Cu}-21 \mathrm{Zn}-5 \mathrm{Al}$ alloy

\begin{tabular}{lcccccc}
\hline Sample & \multicolumn{6}{c}{ Temperature $\left({ }^{\circ} \mathrm{C}\right)$} \\
\cline { 2 - 7 } & $A_{s}$ & $A_{p}$ & $A_{f}$ & $M_{s}$ & $M_{p}$ & $M_{f}$ \\
\hline $\mathrm{Cu}-21 \mathrm{Zn}-5 \mathrm{Al}$ & 275 & 282 & 289 & 197 & 152 & 94.8 \\
\hline
\end{tabular}




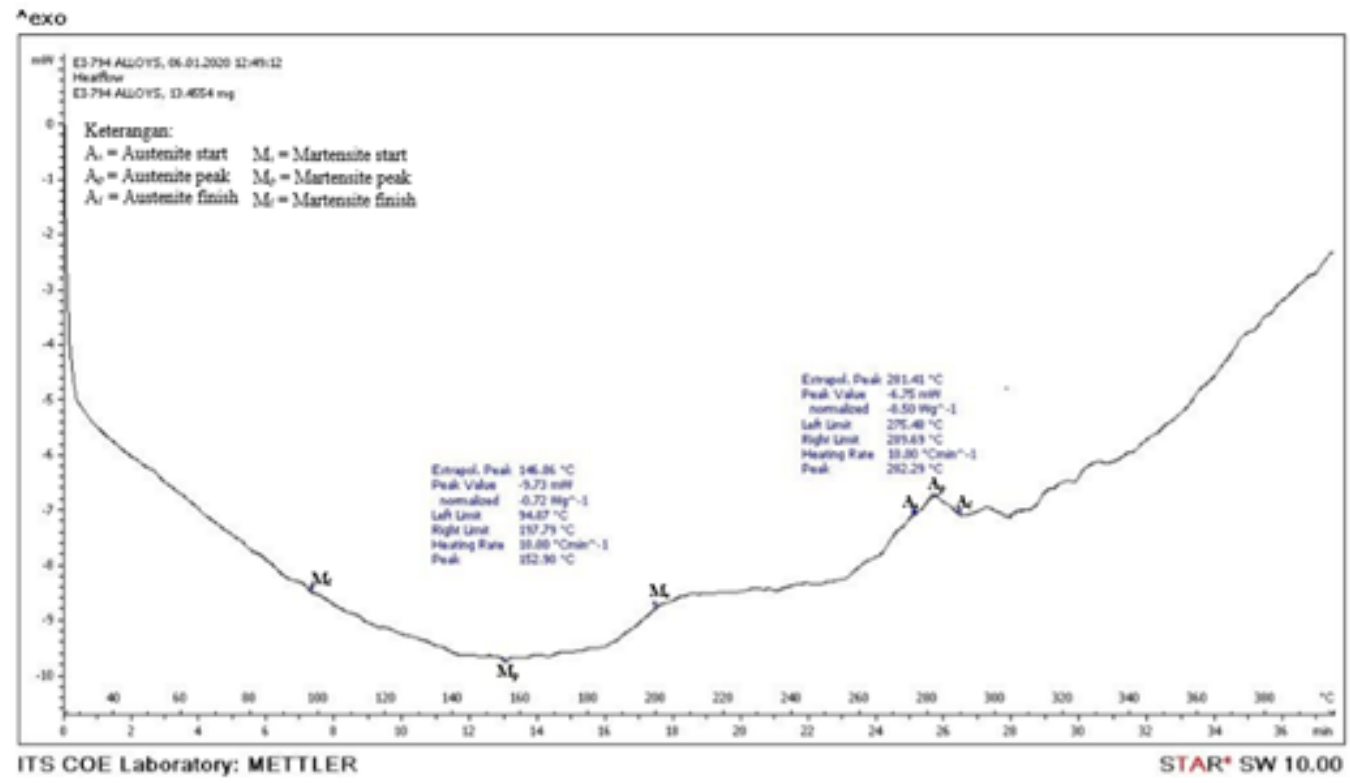

Fig. 9. The DSC pattern of $\mathrm{Cu}-21 \mathrm{Zn}-5 \mathrm{Al}$ alloy

The SME value of $\mathrm{Cu}-21 \mathrm{Zn}-5 \mathrm{Al}$ alloy shown in Table 3 . The sequent of highest to smallest recovery shape value from $\mathrm{Cu}-21 \mathrm{Zn}-5 \mathrm{Al}$ alloy with brine solution are the variation temperature of solution treatment at $850^{\circ} \mathrm{C}(36.67 \%), 900{ }^{\circ} \mathrm{C}(21.67 \%)$, and $750{ }^{\circ} \mathrm{C}$ (13.33\%). On $\mathrm{Cu}-21 \mathrm{Zn}-5 \mathrm{Al}$ alloy with brine solution, $850{ }^{\circ} \mathrm{C}(16.67 \%), 900{ }^{\circ} \mathrm{C}(13.33 \%)$, and $750{ }^{\circ} \mathrm{C}(10 \%)$.

Table 3. The recovery shape of $\mathrm{Cu}-21 \mathrm{Zn}-5 \mathrm{Al}$ alloy

\begin{tabular}{|c|c|c|c|c|c|}
\hline Sample & No. & $\begin{array}{c}\text { Initial } \\
\text { angle }\end{array}$ & $\begin{array}{l}\text { Final } \\
\text { angle }\end{array}$ & $\begin{array}{r}\text { Deviation } \\
\text { angle }\end{array}$ & $\begin{array}{r}\text { Recovery } \\
\text { Shape (\%) }\end{array}$ \\
\hline \multirow{3}{*}{$750-\mathrm{BC}$} & 1 & $20^{\circ}$ & $16^{\circ}$ & $4^{\circ}$ & \multirow{3}{*}{13.33} \\
\hline & 2 & $20^{\circ}$ & $18^{\circ}$ & $2^{\circ}$ & \\
\hline & 3 & $20^{\circ}$ & $18^{\circ}$ & $2^{\circ}$ & \\
\hline \multirow{3}{*}{ 750-DC } & 1 & $20^{\circ}$ & $18^{\circ}$ & $2^{\circ}$ & \multirow{3}{*}{10} \\
\hline & 2 & $20^{\circ}$ & $18^{\circ}$ & $2^{\circ}$ & \\
\hline & 3 & $20^{\circ}$ & $18^{\circ}$ & $2^{\circ}$ & \\
\hline \multirow{3}{*}{$850-\mathrm{BC}$} & 1 & $20^{\circ}$ & $10^{\circ}$ & $10^{\circ}$ & \multirow{3}{*}{36.67} \\
\hline & 2 & $20^{\circ}$ & $13^{\circ}$ & $7^{\circ}$ & \\
\hline & 3 & $20^{\circ}$ & $15^{\circ}$ & $5^{\circ}$ & \\
\hline \multirow{3}{*}{ 850-DC } & 1 & $20^{\circ}$ & $15^{\circ}$ & $5^{\circ}$ & \multirow{3}{*}{16.67} \\
\hline & 2 & $20^{\circ}$ & $18^{\circ}$ & $2^{\circ}$ & \\
\hline & 3 & $20^{\circ}$ & $17^{\circ}$ & $3^{\circ}$ & \\
\hline \multirow{3}{*}{$900-\mathrm{BC}$} & 1 & $20^{\circ}$ & $16^{\circ}$ & $4^{\circ}$ & \multirow{3}{*}{21.67} \\
\hline & 2 & $20^{\circ}$ & $15^{\circ}$ & $5^{\circ}$ & \\
\hline & 3 & $20^{\circ}$ & $16^{\circ}$ & $4^{\circ}$ & \\
\hline \multirow{3}{*}{ 900-DC } & 1 & $20^{\circ}$ & $17^{\circ}$ & $3^{\circ}$ & \multirow{3}{*}{13.33} \\
\hline & 2 & $20^{\circ}$ & $17^{\circ}$ & $3^{\circ}$ & \\
\hline & 3 & $20^{\circ}$ & $18^{\circ}$ & $2^{\circ}$ & \\
\hline
\end{tabular}


The SME mechanism of shape memory alloy occured because reversible phase transformations between the austenite and martensite phases [13]. Therefore, the more martensite phase formed in SMAs, the greater the recovery shape and its SME [14]. Sample 850 -BC have the highest recovery shape because the dominant of martensite phase which is confirmed by the microstructure sample in Figure 7.

\section{Conclusions}

The effect of temperature variation of the treatment solution and the quenching media on the SME of $\mathrm{Cu}-21 \mathrm{Zn}-5 \mathrm{Al}$ alloy is the value of recovery shape depended on the amount of martensite phase formed. The more presence of martensite phase, the greater the value of recovery shape. The highest value of recovery shape is Sample 850-BC with $36.67 \%$.

The effects of temperature variation of the treatment solution and the quenching media on the microstructure of $\mathrm{Cu}-21 \mathrm{Zn}-5 \mathrm{Al}$ alloy are 3 phases formed in all variations, namely $\alpha$, $\beta$, and $\gamma$ phases. In addition to the three phases, martensite or $\beta$ ' phases is formed due to the influence of a rapid quenching media. The microstructure with the most dominant area of martensite phase is Sample 850-BC.

\section{References}

[1] W. Huang, Shape Memory Alloys and their Application to Actuators for Deployable Structures, Britania Raya: University of Cambridge, 1998.

[2] V. Asanovic, and K. Delijic, "The Mechanical Behavior and Shape Memory Recovery of Cu-Zn-Al Alloys", Metalurgija: Journal of Metallurgy, vol. 13, pp. 57-65, 2007.

[3] P.S. Lobo, J. Almeida, L. Guerreiro. "Shape Memory Alloys Behaviour: A Review", Procedia Engineering, vol. 114, pp.776-783, 2015.

[4] M. Sadayappan, Grain Refinement of Permanent Mold Cast Copper Base Alloys. USA: Materials Technology Laboratory, 2004.

[5] ASM International, ASM Handbook Volume 9: Alloy Phase Diagrams. ASM International Handbook Committee, 2004.

[6] C. Newey, and G. Weaver, Materials Principles and Practice. ButterworthHeinemann: Britania Raya, 1990.

[7] ASM International. ASM Handbook Volume 9: Alloy Phase Diagrams. ASM International Handbook Committee, 2004.

[8] A. Molinari, M. Pellizzari, S. Gialanella, G. Straffellini, K.H. Stiasny, "Effect of deep cryogenic treatment on the mechanical properties of tool steels", J. Mater Process Technol. Vol. 118, pp. 350-355, 2001

[9] ASM International, ASM Handbook Volume 3: Metallography and Microstructures, ASM International Handbook Committee, 1992.

[10] L. Babouri, K. Belmokre, A. Kabir, A. Abdelouas, R. Khettabi, Y. El Mendili, "Microstructure and crystallographic properties of Cu77Zn21 alloy under the effect of heat treatment", Materials at High Temperatures, vol. 36 (2), pp.165-172, 2018. 
[11] O.E. Martinez, Y. Cesa, N. Mingolo, R. Romero, "Photoacoustic detection of phase transitions with a resonant piezoelectric scheme with extreme sensitivity to small volume changes", Applied Physics B: Lasers and Optics, vol. 80, pp. 365-371, 2005.

[12] A. Balfas, Analisis Termal Bionanokomposit Filler Serat Kulit Rotan. Bogor: Institut Pertanian Bogor, 2012.

[13] P.K. Kumar, dan D.C. Lagoudas. Shape memory alloys: Modeling and Engineering Applications, US: Springer, 2008.

[14] E. Panjaitan, G.S. Sulistioso, Sumaryo, "Temperatur Transformasi Fasa Shape Memory Alloy - TiNi Hasil Pemaduan Teknik Arc-Melting”, Urania Jurnal Ilmiah Daur Bahan Bakar Nuklir, [S.1.], vol 14, pp. 77-83, 2016. 